East European Journal of Physics

\title{
EFFECT OF SURFACE PRE-TREATMENT ON ADHESIVE STRENGTH OF MULTI-COMPONENT VACUUM-ARC COATINGS
}

\author{
Serhiy V. Lytovchenko ${ }^{\mathrm{a}, *}$, (D)Vyacheslav M. Beresneva, (D) Serhiy A. Klymenko ${ }^{\mathrm{b}}$, \\ (DBohdan O. Mazilina , M.G. Kovaleva ${ }^{c}$, (D)Andrey S. Manohin ${ }^{b}$, Denis V. Horokh ${ }^{a}$, \\ (DIgor V. Kolodiy ${ }^{d}$, V.U. Novikov ${ }^{c}$, (D) Vyacheslav A. Stolbovoy ${ }^{b, d}$, \\ (D) Irina V. Doshchechkina ${ }^{\mathrm{e}}$, (D) Oleg V. Gluhov ${ }^{\mathrm{f}}$ \\ ${ }^{a}$ V.N. Karazin Kharkiv National University, Svobody Sq. 4, 61022, Kharkiv, Ukraine \\ ${ }^{b}$ V.N. Bakul Institute of Superhard Materials of National Academy of Sciences of Ukraine, Avtozavodskaya St., 2, Kiev, Ukraine \\ ${ }^{c}$ Belgorod State National Research University, Pobedy Square, 85, 308015, Belgorod, Russia \\ ${ }^{d}$ National Scientific Center "KIPT" NAS of Ukraine, st. Academic, 1, 61108, Kharkiv, Ukraine. \\ ${ }^{e}$ Kharkiv National Automobile and Highway University, 25, Ya. Mudryi St., 61200 Kharkiv, Ukraine \\ ${ }^{f}$ Kharkiv National University of Radio Electronics, Nauki Ave. 14, 61166, Kharkiv, Ukraine \\ *Corresponding Author: s.lytovchenko@karazin.ua
}

Received September 30, 2020; revised October 14, 2020; last revised November 3, 2020; accepted November 5, 2020

The results of investigations of multi-component nanostructured coatings of (TiAlSiY)N/CrN type are presented. The influence of different variants of substrate surface pretreatment on adhesive strength and hardness of coatings was studied. Pre-treatment of samples was carried out in plasma of two-stage gas discharge according to various technological schemes. Except for ion-plasma purification, some samples were pretreated with a sublayer of chromium within 5 minutes. The coatings were formed by a vacuumarc deposition method at simultaneous spraying of two cathode targets. The first cathode is made of chromium, and the second cathode is made of multicomponent $\mathrm{Ti}$ - Al - Si - Y alloy obtained by vacuum-arc remelting of powder mixture of the mentioned elements. The coatings were deposited on polished stainless-steel substrates at negative $280 \mathrm{~V}$ bias potential. The geometry of the unit and its elements, as well as technological characteristics of the processes of evaporation-condensation were selected so that at a speed of rotation of samples 8 revolutions per minute the formation of the coating with a total thickness of about 9.0 microns occurred in approximately 60 minutes. The analysis of the composition of the coatings shows that the content of elements in the coating differs greatly from the content of elements in the sprayed cathodes. The X-ray diffractometry has shown that all deposition modes are characterized by the formation of phases with cubic (fcc) crystal lattice in both phase layers of multilayer coatings. In the layers formed at spraying of TiAlSiY alloy, a multi-element disordered solid solution (TiAlSiY)N with a crystal lattice of NaCl type and a lattice parameter of $0.4241 \mathrm{~nm}$, as well as chromium mononitride $\mathrm{CrN}$ with a lattice parameter of $0.4161 \mathrm{~nm}$, is determined. It has been established that preliminary formation of a chromium sublayer on the substrate leads to significant changes in adhesive strength of multi-component coatings compared to coatings without a sublayer.

KEYWORDS: multi-component nitride coatings, ionic treatment, surface preparation, adhesive strength, hardness

The analysis of publications on application of functional coatings testifies that the most important properties of wearproof protective coatings should include durability of adhesion of the coatings to a working surface, as well as their hardness [ $1-3]$. It is these properties that determine the ability of coatings to resist external mechanical stresses leading to wear or other destruction. Recently, there has been an intensive development of various technological options for ionplasma synthesis of multilayer coatings based on refractory metal nitrides $[4,5]$. In these options, a targeted change in physical and mechanical properties of coatings is achieved by varying the structural and phase state of protective layers [6]. An essential improvement of performance properties can be achieved with a multi-layer architecture of coatings formed by a consistent or simultaneous use of ion-plasma sources with different evaporated materials, as well as with targeted management of physical and technological parameters of deposition [7].

Adhesion properties of coatings formed by PVD-technologies are determined by various factors: quality of substrate surface preparation, depth of substrate-coating mixing zone, efficiency of the chemical compounds formation in the transition zone, structural defects and stress state of the crystal lattice, segregation of gas impurities, etc. Ion bombardment during deposition has an ambiguous effect on each of the listed factors. Pre-bombardment of substrates with high energy gas ions immediately before coating activates their surface and promotes diffuse interaction at the coating-substrate boundary, but at the same time it also increases defects of the surface and subsurface area (up to $50 \mathrm{~nm}$ ). The desired performance properties of coatings can be achieved only with the right choice and optimization of the entire process cycle, which includes both preliminary preparatory stages and stages of direct coating formation.

The purpose of this work is to study the influence of physical and technological parameters of multi-component coatings (TiAlSiY)N/CrN formation on the strength of adhesion to the substrate, as well as physical and mechanical properties of these coatings.

\section{EXPERIMENTAL AND RESEARCH METHODS}

The coatings were formed by a vacuum-arc deposition method at simultaneous spraying of two cathode targets. One cathode is made of chromium of $\mathrm{X} 99 \mathrm{H}$ grade, and the second cathode is made of Ti - $\mathrm{Al}-\mathrm{Si}-\mathrm{Y}$ alloy obtained by (C) S.V. Lytovchenko, V.M. Beresnev, S.A. Klymenko, B.O. Mazilin, M.G. Kovaleva, A.S. Manohin, D.V. Horokh,

I.V. Kolodiy, V.U. Novikov, V.A. Stolbovoy, I.V. Doshchechkina, O.V. Gluhov, 2020 
vacuum-arc remelting of powder mixture of the mentioned elements taken in the following quantities (at. \%): Ti - 58.5; $\mathrm{Al}-36, \mathrm{Si}-3, \mathrm{Y}-2.5$. The coatings were deposited on the mechanically polished surface of $15 \mathrm{~mm} \times 15 \mathrm{~mm} \times 2.5 \mathrm{~mm}$ samples made of $12 \mathrm{X} 18 \mathrm{H} 9 \mathrm{~T}$ steel. The working pressure of nitrogen during deposition $\left(\mathrm{P}_{\mathrm{N}}\right)$ was 0.6 Pa. When forming coatings, the cathodes were placed in separate evaporators located on opposite walls of the vacuum chamber on one axis towards the center. In the center of the chamber there was a rotary device, on which samples were fixed in the normal direction to the axis. This device with samples during deposition rotated at a speed of $8 \mathrm{rpm}$. To obtain thicker coating layers, the rotary device was stopped at the corresponding cathode for a time sufficient to achieve the required thickness. The formation of the coating with a total thickness of about 9.0 microns was complete in approximately 60 minutes.

To clean the substrate surfaces before coating, they were pre-treated for 5 minutes in the plasma of a two-stage gas discharge [8] at different types (nitrogen or argon) and its pressure $\left(\mathrm{P}_{\mathrm{N}}, \mathrm{P}_{\mathrm{Ar}}\right)$ in the chamber, the duration of cleaning when bombarding the substrate with chromium ions $\left(t_{\mathrm{Cr}}\right)$, at different values of the negative potential on the substrate $\left(\mathrm{U}_{\mathrm{p}}\right)$. Some samples were previously deposited with a sublayer of $\mathrm{Cr}(+)$ for 5 minutes, the remaining samples were without a sublayer $\mathrm{Cr}(-)$. Specific modes of pre-treatment are given in Table 1.

A 4 series of samples were produced using various parameters of pre-treatment of sample surface (Table 1). In all experiments, the following parameters were kept constant: arc current $\mathrm{I}_{\mathrm{a}}=90 \mathrm{~A}$, and focusing coil current $\mathrm{I}_{\mathrm{f}}=0.5 \mathrm{~A}$.

The coatings on the samples of series 1-4 were formed within 60 minutes at a negative displacement potential on the substrate $\mathrm{U}_{\mathrm{b}}=280 \mathrm{~V}$.

Table 1.

Modes of substrate surface pre-treatment and cleaning time

\begin{tabular}{|c|c|c|c|c|}
\hline Series No. & $\mathrm{P}_{\mathrm{N}}, \mathrm{P}_{\mathrm{Ar}}, \mathrm{Pa}$ & cleaning time $\mathrm{t}_{\mathrm{Cr}}$, minutes & $\mathrm{U}_{\mathrm{p}}, \mathrm{B}$ & $\mathrm{Cr}:+/-$ \\
\hline 1 & $\mathrm{P}_{\mathrm{N}}=0.3$ & 30 & -1000 & + \\
\hline 2 & $\mathrm{P}_{\mathrm{N}}=0.3$ & 20 & -1000 & - \\
\hline 3 & $\mathrm{P}_{\mathrm{N}}=0.3$ & 20 & -1000 & + \\
\hline 4 & $\mathrm{P}_{\mathrm{Ar}}=0.2$ & 20 & -500 & + \\
\hline
\end{tabular}

Microscopic examination of coating surface was performed using a Nova NanoSEM 450 scanning electron microscope. The elemental composition of coatings was determined by the spectra of the characteristic X-ray radiation generated by the electron beam in the scanning electron microscope. The spectra were obtained with a EDAX PEGASUS energy-dispersion spectrometer installed in the microscope. The coatings thickness was measured using images of transverse grinding of samples with coatings obtained by raster electron microscopy.

The phase composition of coatings was determined by X-ray diffractometry on DRON-4 in Cu- $\mathrm{K}_{\alpha}$-radiation with graphite monochromator by the Bragg-Brentano method. The analysis of substructural characteristics (the size of coherent OCD scattering areas and the level of microstrain) was carried out using integral width of diffraction lines (the Williamson-Hall method).

Macrostresses in the samples were determined by the $\sin ^{2} \psi$ method.

Microhardness of coatings was measured on a AFFRI DM-8 hardness tester by the micro-Vickers method at $50 \mathrm{~g}$ indenter load. Values obtained by averaging data on 10 injections are given for each sample type.

Adhesion/cohesion strength of coatings was determined by sclerometry using a Revetest scratch tester (CSM Instruments). The tests recorded changes in the coefficient of friction and acoustic emission at the growth of the scraping load, as well as recorded the main critical loads: $\mathrm{L}_{C l}$ - formation of the first chevron crack at the bottom and diagonal cracks at the scratch edges; $\mathrm{L}_{C 2}$ - groups of chevron cracks at the scratch bottom; $\mathrm{L}_{C 3}$ - local peeling of coating after formation of set of chevron cracks at the scratch bottom; $\mathrm{L}_{C 4}$ - cohesive-adhesive destruction of coating; $\mathrm{L}_{C 5}$ - plastic abrasion of coating to the substrate $[9,10]$. Critical load $\mathrm{L}_{C 5}$ leading to coating failure was taken as a criterion of adhesive strength. Two scratches were made on each sample to increase data reliability and reliability of results.

\section{RESULTS AND DISCUSSION}

The electron-microscopic research and analysis of the morphology of the substrate surface after the gas discharge treatment (Fig. 1a) and the coating surface (Fig. 1b) show that the surface is quite smooth, but both the defect level and the share/fraction of the droplet component on it are quite high.

The presence of the coating droplet fraction and cathode macroparticles on the surface is typical for the majority of condensates obtained from non-separated plasma flows by the vacuum-arc deposition method. In addition to the droplet component, there is a small number of macroparticles on the surface that locally distort the layered geometry of the coating.

The analysis of elemental composition of coatings (Fig. 2, Table 2) showed the presence of evaporable cathodes $(\mathrm{Cr}, \mathrm{Ti}, \mathrm{Al}, \mathrm{Si}, \mathrm{Y})$ and nitrogen (reaction gas in the chamber during coating deposition) in all samples of the initial elements. The content of elements in the coating differs greatly from the content of elements in the sputtering cathodes. This is due to a significant difference in the partial pressures of the elements vaporized from the cathodes and the degree of their dispersion, as well as different characteristics of the interaction of the substrate surface with different plasma flow particles. 


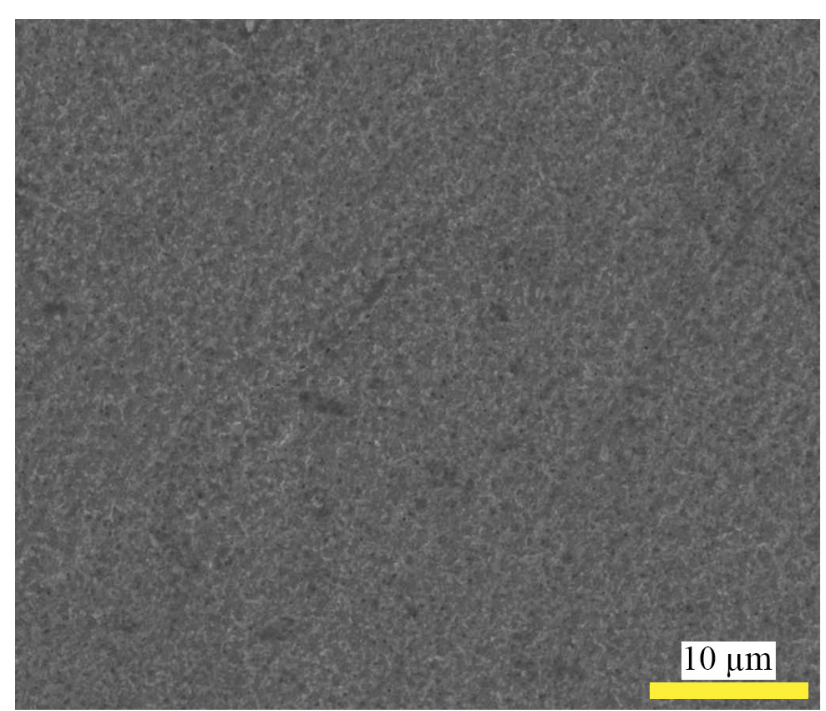

a

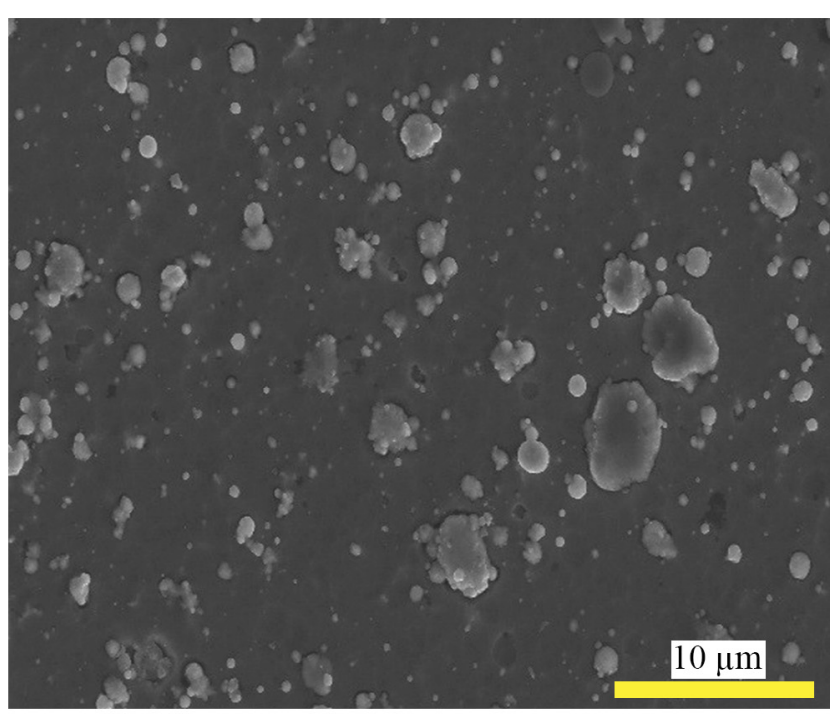

b

Figure 1. Surface morphology of sample series 1: a) after treatment in a gas discharge b) after coating formation

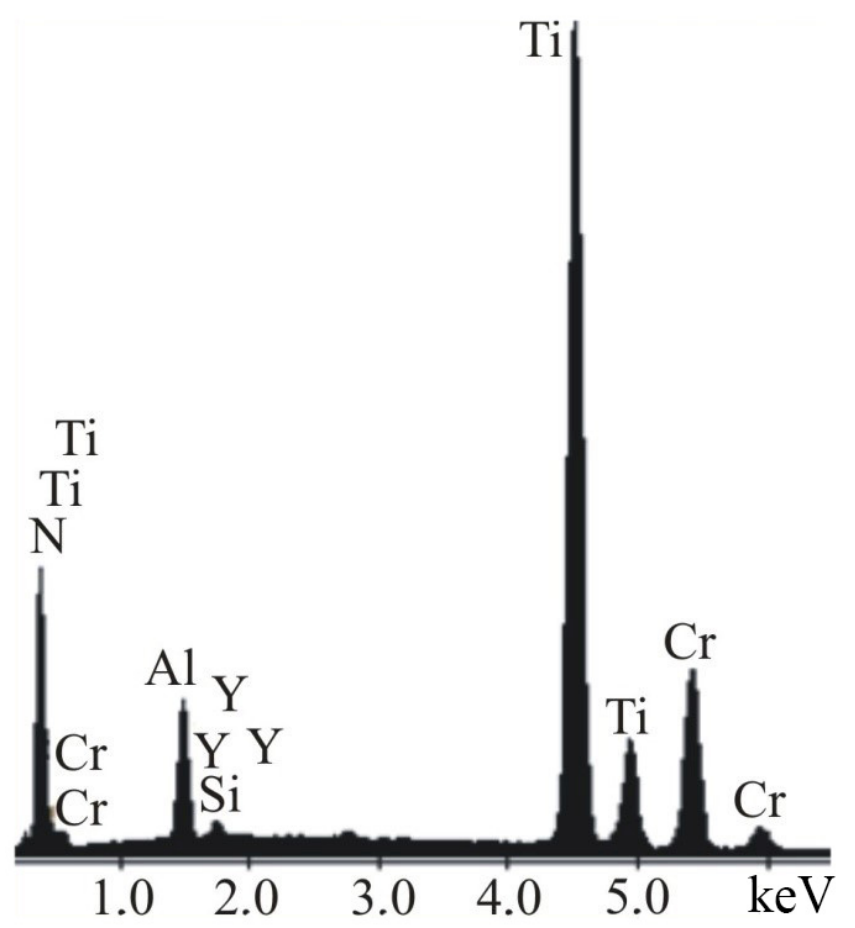

Figure 2. Section of energy dispersion spectrum of coatings

Elemental composition of coatings (TiAlSiY)N/CrN according to EDA data

Table 2.

\begin{tabular}{|c|c|c|c|c|c|c|}
\hline \multirow{2}{*}{$\begin{array}{l}\text { Series } \\
\text { No. }\end{array}$} & \multicolumn{6}{|c|}{ Contents of elements, at. \% } \\
\cline { 2 - 7 } & $\mathrm{N}$ & $\mathrm{Ti}$ & $\mathrm{Al}$ & $\mathrm{Cr}$ & $\mathrm{Si}$ & $\mathrm{Y}$ \\
\hline 1 & 27.9 & 36.5 & 7.9 & 26.7 & 0.7 & 0.3 \\
\hline 2 & 28.6 & 36.4 & 8.5 & 25.1 & 0.8 & 0.6 \\
\hline 3 & 29.2 & 32.2 & 8.6 & 29.2 & 0.7 & 0.1 \\
\hline 4 & 27.6 & 36.8 & 7.7 & 27.0 & 0.7 & 0.2 \\
\hline
\end{tabular}

The analysis of the results obtained for the elemental composition of coatings (see Table 2) shows that the element concentration in coatings substantially depends on the energy of the plasma flow particles.

The analysis of diffraction spectra (Fig. 3) shows that formation of phases with cubic (GCC) crystal lattice in both layers of multilayer coatings is typical for the obtained coatings. 


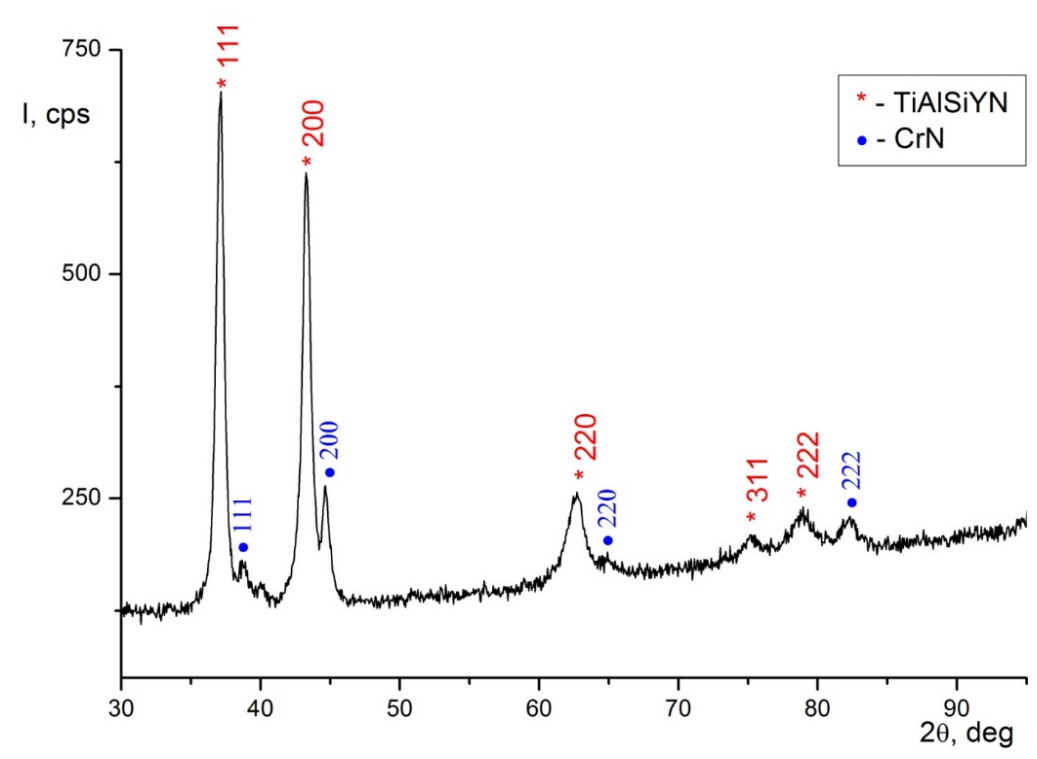

Figure 3. TiAlSiYN/CrN coating diffraction spectrum section

It should be noted that the formation of multielement GCC structures in nitride coatings is confirmed by many researchers $[11,12]$. The analysis of publications suggests that for such materials, the formation of a single-phase solid solution of complex multi-element nitride phase is energetically more favourable than the formation of a number of separate coexisting simple nitrides.

According to the X-ray data in the nitride layers based on a TiAlSiY alloy, a disordered solid solution (TiAlSiY)N with a crystal lattice of the structural type $\mathrm{NaCl}$ and chromium mononitride $\mathrm{CrN}$ were registered. The analysis of $\mathrm{X}$-ray line intensities points to the presence of a strong texture (111) in the multi-element $\mathrm{CrN}$ nitride and chromium nitride the grains of these phases are mainly oriented in such a way that their crystallographic planes (111) are parallel to the sample surface. The lattice parameter of the nitride multi-component phase is $0.4241 \mathrm{~nm}$. The macrostress level reaches $\sigma \varphi=-5.39 \mathrm{GPa}$. The calculation of substructural properties of this phase shows that the size of OCD is $14.6 \mathrm{~nm}$ with a significant level of microstrain - up to $5.81 \cdot 10^{-3}$. The parameter of the $\mathrm{CrN}$ chromium mononitride lattice is $0.4161 \mathrm{~nm}$, but the substructural properties of this phase could not be determined.

The determination of macrostresses was carried out along the main phase lines (TiAlSiY)N on the assumption that the diffraction lines intensity in the precision region was sufficient. The calculation was based on a number of assumptions. Firstly, since the values of Poisson's coefficient v and Young's E modulus for the (TiAlSiY)N phase could not be found in reported scientific sources, these values for the phase TiAlN: $v=0.25$ and $\mathrm{E}=378 \mathrm{GPa}$ [1] were used. Secondly, for textured samples, the anisotropy of the Young's modulus was not taken into account [13]. In this case, the similarity of structural states in the nitride interlayers based on the TiAlSiY alloy and nitrides of transition metals of Group VI (close ratio of the formed preferential orientations of crystallites in the interlayers) indicates the interrelation of the structures of the layers during their growth.

Hardness is known to be one of the most important mechanical properties. The results of microhardness measurements of coatings are given in Table 3 .

Table 3.

Microhardness of coatings (TiAlSiY)N/CrN

\begin{tabular}{|c|c|c|c|c|}
\hline Series No. & 1 & 2 & 3 & 4 \\
\hline $\mathrm{H}_{\mu}, \mathrm{GPa}$ & 36.5 & 30.0 & 31.1 & 34.4 \\
\hline
\end{tabular}

However, apart from high hardness combined with sufficient viscosity, the material of nanocomposite coatings must have high adhesive strength.

The determination of the adhesion indices of coatings and analysis of the process of their destruction were carried out on the basis of data from scratch testing of samples in a mode of continuous linear increase in load on the indenter while its simultaneous linear movement on the sample surface. Fig. 4 presents diagrams of changes in amplitude of acoustic emission (the blue curve), friction coefficient (the red curve) and microphotographs of the surface of (TiAlSiY)N/CrN plasma coatings in samples of Series 1 and 2 at different stages of indenter loading (left pictures - at loading $\mathrm{L}_{C l}$, right pictures - at loading $\mathrm{L}_{C 5}$ respectively).

For the sample of Series 1 (see Table 1) the comparative analysis of structural features of a scratch allows to conclude that at loading less than $21.5 \mathrm{~N}\left(\mathrm{~L}_{C l}\right)$ the indenter leaves practically no traces on the coating. At high loads, both chevron cracks at the bottom of a scratch and diagonal cracks begin to appear. This is due to the presence of defects on the surface of the coating, as well as in the volume of vacuum-arc coating. When diagonal cracks close along the banks of a scratch, the detachment of individual scales is observed. The formation of such cracks is accompanied by 
a monotonic increase in the friction coefficient up to 0.42 . At $188.6 \mathrm{~N}\left(\mathrm{~L}_{C 5}\right)$ load, the indenter reaches the substrate at the bottom of the scratch.

For the sample of Series 2, the level of $\mathrm{L}_{C l}$ was $21.7 \mathrm{~N}$ and $\mathrm{L}_{C 5}-150.1 \mathrm{~N}$, respectively. The analysis of coating failure on this sample shows that the initial stage of failure is due to both surface and volume defects.

Interestingly, at the initial stages of loading (approximately to the value of $\mathrm{L}_{C l}$ ) almost no acoustic emission signals are registered, although the adhesion of the indenter with the surface of the sample is growing. This confirms an increase in friction coefficient to the values of 0.3-0.36, which is close to a linear increase. With a further increase in the load on the indenter, signals of acoustic emission are registered, but their level and intensity is relatively small, which indicates the absence of active cracking in coatings.
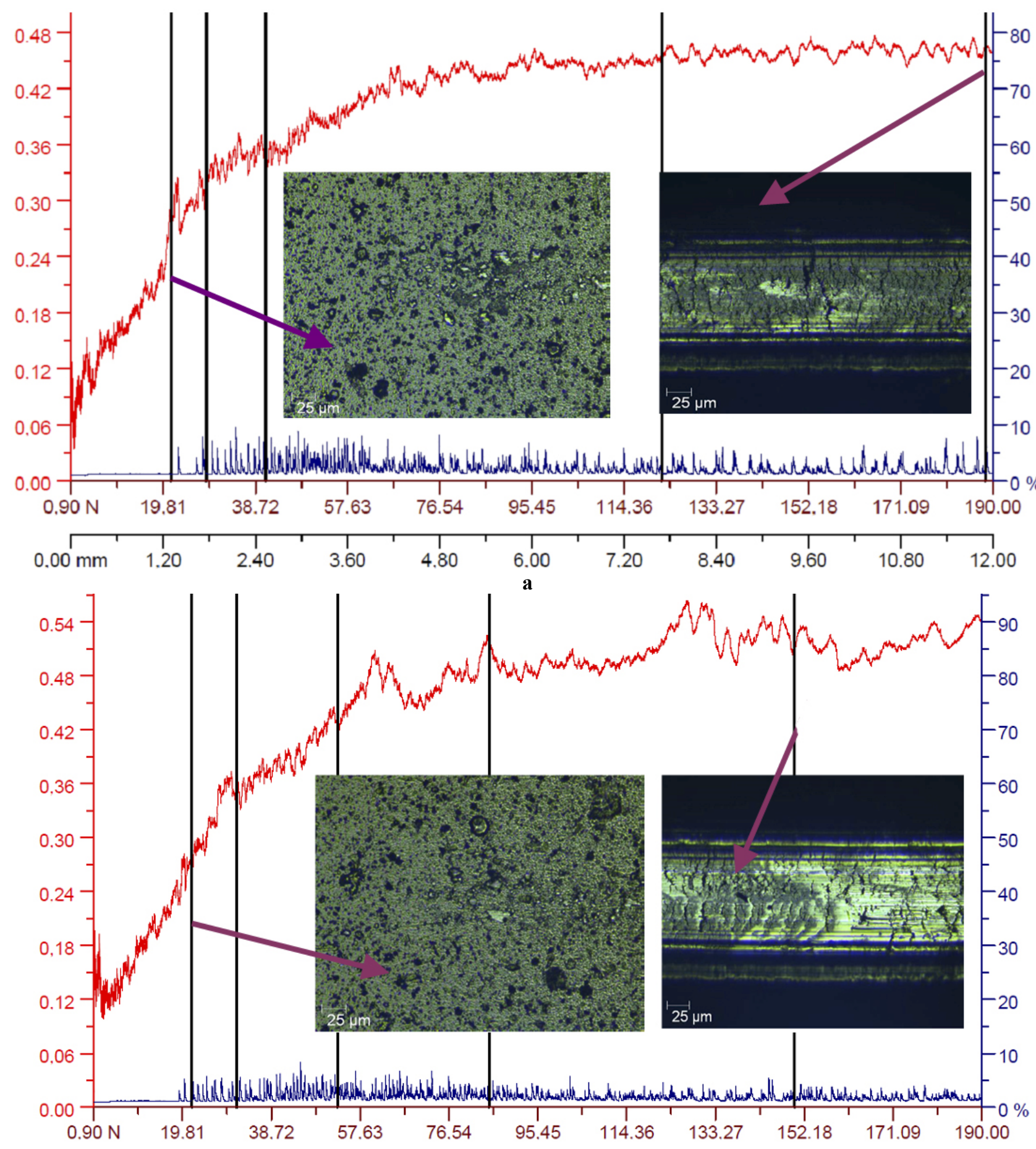

\begin{tabular}{|c|c|c|c|c|c|c|c|c|c|}
\hline $0.00 \mathrm{~mm}$ & 1.20 & 240 & 360 & 4.80 & 6.00 & 720 & 8.40 & 9.60 & 10.80 \\
\hline
\end{tabular}

b

Figure 4. Scratch testing data of coatings (TiAlSiY)N/CrN obtained from straight-flow plasma beam $\mathrm{a}$ - Series 1, loads $21.5 \mathrm{~N}\left(\mathrm{~L}_{C l}\right)$ and $188.6 \mathrm{~N}\left(\mathrm{~L}_{C 5}\right) ; \mathrm{b}$ - Series 2, loads $21.7 \mathrm{~N}\left(\mathrm{~L}_{C l}\right) ; 150.1 \mathrm{~N}\left(\mathrm{~L}_{C 5}\right)$ 
Average values of critical loads at different stages of coating destruction (TiAlSiY)N/CrN

Table 4

\begin{tabular}{|c|c|c|c|c|c|}
\hline \multirow{2}{*}{$\begin{array}{c}\text { Series } \\
\text { No. }\end{array}$} & \multicolumn{5}{|c|}{$L c, \mathrm{~N}$} \\
\cline { 2 - 6 } & 1 & 2 & 3 & 4 & 5 \\
\hline 1 & 21.5 & 28.6 & 40.9 & 122.0 & 188.6 \\
\hline 2 & 21.7 & 41.3 & 52.8 & 85.1 & 150.1 \\
\hline 3 & 21.8 & 27.5 & 44.5 & 69.8 & 180.9 \\
\hline 4 & 22.9 & 28.2 & 39.0 & 78.8 & 186.4 \\
\hline
\end{tabular}

The comparative analysis of coating destruction shows that the coatings wears out but do not peel off during scratching, i.e. they are destroyed by the cohesive mechanism associated with plastic deformation and formation of fatigue cracks in the coating material [13]. Differences in the adhesive strength of coatings are due to both mechanical interaction of the indent with the surface, which is influenced by the roughness of the contact surfaces, and physical and chemical interatomic interaction on the boundary of contacting bodies.

The analysis of sclerometry data confirms a positive effect of the chromium sublayer on the properties of coatings, which have a sufficiently high level of adhesive strength (Table 4) and an acceptable hardness (Table 3).

All obtained coatings have, on the one hand, a rather low coefficient of friction (maximum $\mu=0.42-0.48$ at high loads) determined by a low value of shear resistance. On the other hand, they have a sufficiently high hardness and strength of the surface layer, which determine resistance to mechanical destruction and wearing.

An essentially narrower spread in values of the coefficient of friction at loads $>\mathrm{L}_{C 3}$ in the Series 1 coating with a chrome sublayer (Fig. 4, a) in comparison with similar properties of the Series 2 coating without a sublayer (Fig. 4, b) also confirms a positive influence of the chrome layer on the homogeneity and quality of the coating surface.

\section{CONCLUSIONS}

It is typical for all (TiAlSiY)N/CrN type coatings obtained by vacuum-arc deposition to have phases with cubic (GCC) crystal lattice formed in both layers of multilayer coatings. Compressive stresses $\sigma \varphi=-5.39 \mathrm{GPa}$ have been recorded in (TiAlSiY)N layers. The lattice parameter of this phase is $0.4241 \mathrm{~nm}$, which slightly exceeds the lattice parameter of chromium mononitride $\mathrm{CrN}(0.4161 \mathrm{~nm})$.

The coatings formed on substrates with pre-deposited chromium sublayer have higher hardness $(\mathrm{H}=36.5 \mathrm{GPa})$ compared to similar samples without such a sublayer $(\mathrm{H}=30.0 \mathrm{GPa})$. The presence of the chromium layer also contributes to the adhesion strength of (TiAlSiY)N/CrN coatings on substrates made of X18H10T steel. Critical values of fracture load for coatings with a chromium sublayer reach $\mathrm{L}_{C 5}=188.6 \mathrm{~N}$, and without a chromium sublayer $-\mathrm{L}_{C 5}=150.1 \mathrm{~N}$.

The obtained coatings have a relatively low of friction coefficient (at high loads $\mu_{\max }=0.42-0.48$ ), high hardness and strength.

\section{ORCID IDs}

Derhiy V. Lytovchenko, https://orcid.org/0000-0002-3292-5468; (DVyacheslav M. Beresnev, https://orcid.org/0000-0002-4623-3243; (D) Serhiy A. Klymenko, https://orcid.org/0000-0003-1464-3771; DBohdan O. Mazilin, https://orcid.org/0000-0003-1576-0590; (D)Andrey S. Manohin, https://orcid.org/0000-0003-1479-8482; DDenis V. Horokh, https://orcid.org/0000-0002-6222-4574;

Igor V. Kolodiy, https://orcid.org/0000-0001-8598-9732; DVyacheslav A. Stolbovoy, https://orcid.org/0000-0001-7734-0642; DIrina V. Doshchechkina, https://orcid.org/0000-0002-6278-7780; DOleg V. Gluhov, https://orcid.org/0000-0003-2453-5504.

[1] A. D. Pogrebnjak, O. M. Ivasishin, and V.M. Beresnev, Usp. $\quad$ Fiz. $\quad$ Met. $\quad$ 17(1), $1-28 \quad$ (2016), https://doi.org/10.15407/ufm.17.01.001. 330-336 (2017), https://doi.org/10.1016/j.surfcoat.2017.01.001.

[3] M.M. Mamonova, V.V. Prudnikov, and I.A. Prudnikova, Физика поверхности. Теоретические модели и экспериментальные методы [Surface physics. Theoretical models and experimental methods], (Fizmatlit, Moscow, 2011), pp. 400. (in Russian).

[4] M. Naveed, A. Obrosov, A. Zak, W. Dudzinski, A. Volinsky, and S. Weiß, Metals, 6, 265 (2016), https://doi.org/10.3390/met6110265.

[5] K.V. Smyrnova, A.D. Pogrebnjak, V.M. Beresnev, S.V. Litovchenko, S.O. Borba Pogrebnjak, A.S. Manokhin, S.A. Klimenko, B. Zhollybekov, A.I. Kupchishin, Ya.O. Kravchenko, and O.V. Bondar, Metals and Materials International, 24(5), 1024-1035 (2018), https://doi.org/10.1007/s12540-018-0110-y.

[6] N. Koutná, P. Řehák, Z. Chen, M. Bartosik, M. Fallmann, M. Černý, Z. Zhang, M. Friák, M. Šob, P.H. Mayrhofer, and D. Holec, Scripta Materialia, 165, 159-163 (2019), https://doi.org/10.1016/j.scriptamat.2019.02.021.

[7] I.I. Aksionov, A.A. Andreyev, V.A. Belous, V.Ye. Strel 'nitskiy, and V.M. Khoroshikh, Вакуумная дуга: источники плазмы, осаждение покрытий, поверхностное модифицирование [Vacuит arc: plasma sources, deposition of coatings, surface modification], (Naukova dumka, Kiev, 2012), pp. 727. (in Russian). 
[8] A.O. Andreev, V.M. Pavlenko, and Iu.O. Sysoiev, Технологія машинобудування. Основи отримання вакуумно-дугових покриттів [Mechanical engineering technology. Basics of obtaining vacuum-arc coatings], (KhAI Publishing House, Kharkiv, 2018), pp. 139-145. (in Ukrainian).

[9] J. Sekler, P.A. Steinmann, and H.E. Hintermann, Surface and Coatings Technology, 36(1-2), 519-529 (1988), https://doi.org/10.1016/0257-8972(88)90179-X.

[10] J. Valli, Journal of Vacuum Science and Technology A, 4(6), 3007-3014 (1986), https://doi.org/10.1116/1.573616.

[11] A.D. Pogrebnjak, A.A. Bagdasaryan, I.V. Yakushchenko, and V.M. Beresnev, Russian Chemical Reviews, 83(11), 1027-1061 (2014), https://doi.org/10.1070/rcr4407.

[12] R. Chen, Z. Cai, J. Pu, Z. Lu, S. Chen, S. Zheng, and C. Zeng, Journal of Alloys and Compounds, 827, 153836 (2020), https://doi.org/10.1016/j.jallcom.2020.153836.

[13] R. Radhika, and D. Arivuoli, Indian Journal of Physics, 87(12), 1199-1206 (2013), https://doi.org/10.1007/s12648-013-0359-4.

[14] I.D. Ibatullin, Кинетика усталостной повреждаемости и разрушения поверхностных слоев: монография [Кіпетісs оf Fatigue Damage and Fracture of Surface Layers: Monograph], (Samara, Samara Tech. Univ., 2008), pp. 387. (in Russian).

\section{ВПЛИВ ПОПЕРЕДНЬОЇ ОБРОБКИ ПОВЕРХНІ НА АДГЕЗІЙНУ МІЦНІСТЬ БАГАТОКОМПОНЕНТНИХ} ВАКУУМНО-ДУГОВИХ ПОКРИТТІВ

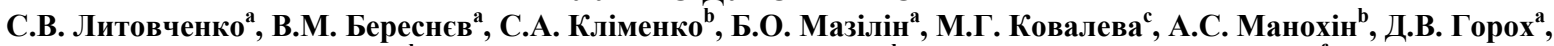
І.В. Колодій ${ }^{\mathrm{d}}$, В.Ю. Новіков ${ }^{\mathrm{c}}$, В.А. Столбовой ${ }^{\mathrm{ad}}$, І.В. Дощечкіна ${ }^{\mathrm{e}}$, О.В. Глухов

${ }^{a}$ Харківський національний університет імені В.Н. Каразіна, майдан Свободи 4, 61022, м. Харків, Украйна

${ }^{b}$ Інститут надтвердих матеріалів ім. В.М. Бакуля НАН Украйни, вул. Автозаводська, 2, 04074, м. Київ, Украӥна ${ }^{c}$ Бєлгородський державний наџіональний дослідницький університет, вул. Перемоги, 85, 308015, м. Бєлгород, Росія

${ }^{d}$ Наиіональний науковий центр «Харківський фізико-технічний інститут», вул. Академічна, 1, 61108, м. Харків, Украйна

еХарківський начіональний автомобільно-дорожній університет, вул. Ярослава Мудрого, 25, 61002, м. Харків, Украӥна

${ }^{f}$ Харківський наџіональний університет радіоелектроніки, проспект Науки, 14, 61166, г. Харків, Украйна

Представлені результати досліджень багатокомпонентних наноструктурних покриттів типу (TiAlSiY)N/CrN. Bивчено вплив різних варіантів попередньої підготовки поверхні підкладинок на адгезійну міцність і твердість покриттів. Попередню обробку зразків проводили в плазмі двоступеневого газового розряду за різними технологічними схемами. Крім іонноплазмового очищення на частину зразків попередньо протягом 5 хвилин напилювали підшар хрому. Покриття формували методом вакуумно-дугового осадження при одночасному розпиленні двох катодів-мішеней. Один катод виготовлений 3 хрому, а інший - з багатокомпонентного сплаву $\mathrm{Ti}-\mathrm{Al}-\mathrm{Si}-\mathrm{Y}$, отриманого вакуумно-дуговим переплавом суміші порошків зазначених елементів. Покриття осаджували на поліровані підкладинки з нержавіючої сталі при негативних потенціалах зміщення 280 В. Геометрія установки і iї елементів, а також технологічні характеристики процесів випаровування-конденсації були підібрані так, що при швидкості обертання зразків 8 обертів за хвилину формування покриття загальною товщиною близько 9,0 мкм відбувалося приблизно за 60 хвилин. Аналіз елементного складу покриттів показав, що вміст елементів в покритті значно різнится порівняно з вмістом цих елементів у розпорошених катодах. Рентгенівська дифрактометрія показала, що для всіх режимів осадження характерним є утворення фаз з кубічними (ГЦК) кристалічними гратами в обох фазних прошарках багатошарових покриттів. У прошарках, сформованих при розпилюванні сплаву TiAlSiY, зафіксовано багатоелементний невпорядкований твердий розчин (TiAlSiY)N 3 кристалічними гратами структурного типу $\mathrm{NaCl}$ і параметром 0,4241 нм, а також мононітрид хрому $\mathrm{CrN} 3$ параметром гратів 0,4161 нм. Встановлено, що попереднє формування підшару хрому на підкладинці призводить до суттєвої зміни адгезійної міцності багатокомпонентного покриття у порівнянні з покриттям без підшару.

КЛЮЧОВІ СЛОВА: багатокомпонентні нітридні покриття, іонна обробка, підготовка поверхні, адгезійна міцність, твердість

\section{ВЛИЯНИЕ ПРЕДВАРИТЕЛЬНОЙ ОБРАБОТКИ ПОВЕРХНОСТИ НА АДГЕЗИОННУЮ ПРОЧНОСТЬ МНОГОКОМПОНЕНТНЫХ ВАКУУМНО-ДУГОВЫХ ПОКРЫТИЙ}

\section{С.В. Литовченко ${ }^{a}$, В.М. Береснев ${ }^{a}$, С.А. Клименко ${ }^{\text {, }}$, Б.А. Мазилин ${ }^{a}$, М.Г. Ковалева ${ }^{c}$, А.С. Манохин $^{\text {B }}$, Д.В. Горох ${ }^{a}$,} И.В. Колодий ${ }^{\mathrm{d}}$, В.Ю. Новиков ${ }^{\mathrm{c}}$, В.А. Столбовой ${ }^{\mathrm{a}, \mathrm{d}}$, И.В. Дощечкина ${ }^{\mathrm{e}}$, О.В. Глухов

${ }^{a}$ Харьковский национальный университет имени В.Н. Каразина, пл. Свободы, 4, 61022, г. Харьков, Украина

${ }^{b}$ Институт сверхтвердых материалов им. В.Н. Бакуля НАН Украины, ул Автозаводская, 2, 04074, г. Киев, Украина ${ }^{c}$ Белгородский государственный национальный исследовательский университет, ул. Победы, 85, 308015, г. Белгород, Россия ${ }^{d}$ Начиональный научный иентр «Харьковский физико-технический институт», ул. Академическая, 1, 61108, г. Харьков, Украина ${ }^{e}$ Харьковский национальный автомобильно-дорожный университет, ул. Ярослава Мудрого, 25, 61002, г. Харьков, Украина

${ }^{f}$ Харьковский национальный университет радиоэлектроники, проспект Науки, 14, 61166, г. Харьков, Украина

Представлены результаты исследований многокомпонентных наноструктурных покрытий типа (TiAlSiY)N/CrN. Изучено влияние различных вариантов предварительной подготовки поверхности подложек на адгезионную прочность и твердость покрытий. Предварительную обработку образцов проводили в плазме двухступенчатого газового разряда по различным технологическим схемам. Кроме ионно-плазменной очистки на часть образцов предварительно в течение 5 минут напыляли подслой хрома. Покрытия формировались методом вакуумно-дугового осаждения при одновременном распылении двух катодов-мишеней. Один катод изготовлен из хрома, а другой - из многокомпонентного сплава $\mathrm{Ti}-\mathrm{Al}-\mathrm{Si}-\mathrm{Y}$, полученного вакуумно-дуговым переплавом смеси порошков указанных элементов. Покрытия осаждали на полированные подложки из нержавеющей стали при отрицательных потенциалах смещения 280 В. Геометрия установки и ее элементов, а также технологические характеристики процессов испарения - конденсации были подобраны так, что при скорости вращения образцов 8 оборотов в минуту формирование покрытия общей толщиной около 9,0 мкм происходило приблизительно за 60 минут. Анализ элементного состава покрытий показал, что содержание элементов в покрытии сильно отличается от содержания элементов в распыленных катодах. Рентгеновская дифрактометрия показала, что для всех режимов осаждения характерно образование фаз с кубической (ГЦК) кристаллической решеткой в обеих фазных прослойках многослойных 
покрытий. В прослойках, сформированных при распылении сплава TiAlSiY, определяется многоэлементный неупорядоченный твердый раствор (TiAlSiY)N с кристаллической решеткой структурного типа $\mathrm{NaCl}$ и параметром решетки 0,4241 нм, а также мононитрид хрома CrN с параметром решетки 0,4161 нм. Установлено, что предварительное формирование подслоя хрома на подложке приводит к существенному изменению адгезионной прочности многокомпонентного покрытия по сравнению с покрытием без подслоя.

КЛЮЧЕВЫЕ СЛОВА: многокомпонентные нитридные покрытия, ионная обработка, подготовка поверхности, адгезионная прочность, твердость 